\title{
Effect of slaughter weight on the carcass value of young crossbred ('Polish Holstein Friesian' $x$ 'Limousin') steers and bulls
}

\author{
Zenon Nogalski ${ }^{1}$, Zofia Wielgosz-Groth ${ }^{1}$, Cezary Purwin $^{1}$, Monika Sobczuk-Szul ${ }^{1}$, Magdalena Mochol $^{1}$, \\ Paulina Pogorzelska-Przybyłek $^{1}$, and Rafał Winarski ${ }^{1}$
}

\begin{abstract}
Apart from others factors, carcass quality is determined by the animal's age and body weight (BW) at the end of the fattening period. The aim of this study was to determine the optimum finishing weight of young crossbred 'Polish Holstein Friesian' $(\mathrm{PHF}) \times$ 'Limousin' (LIM) steers and bulls, based on their slaughter value. The experimental materials comprised 60 animals, including 30 bulls and 30 steers, fed farm-made feeds. At 2 or 3 wk of age, one half of calves were castrated. Bloodless castration was carried out using a rubber elastrator. Calves were reared under a conventional system, and were fattened semi-intensively. Daily gains ranged from 800 to $950 \mathrm{~g}$. Calves were fattened to $450,500,550$, or $600 \mathrm{~kg}$ BW. Carcass value was estimated after slaughter. Fatty acid profile was determined by gas chromatography in fat extracted from samples of muscle longissimus dorsi (MLD). Bulls, compared with steers, were characterized by a higher slaughter value, including a higher carcass dressing percentage by $1.07-2.60 \%$, higher carcass conformation, and lower carcass fatness. In steers, an increase in live BW was accompanied by a considerable increase in fat content (higher than bulls), as confirmed by a significant $(\mathrm{p} \leq 0.01)$ interaction. The intramuscular fat of bulls was characterized by higher concentrations of fatty acids delivering health benefits, and a more desirable polyunsaturated fatty acids/saturated fatty acids (PUFA/SFA) ratio.

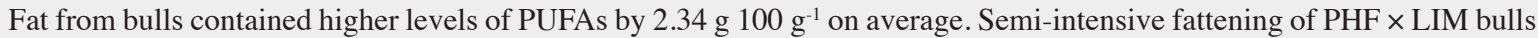
to slaughter weight of $600 \mathrm{~kg} \mathrm{BW}$ is recommended due to an increase in carcass value. Steers should be fattened to slaughter weight of 500-550 kg BW to prevent excessive fat deposition.
\end{abstract}

Key words: Bulls, fatness, fatty acids, slaughter value, slaughter weight, steers.

\section{INTRODUCTION}

Beef, which together with milk belongs to the most important bovine products, has a high nutritional value. In Poland, similarly as in many other countries (mostly European), beef production is based mainly on dairy cattle breeds. The carcasses of dairy cattle have a low dressing percentage, their meat is less valuable and cheaper than beef cattle meat, and it is mostly used as raw material for further processing. Thus, beef producers relying on dairy herds cannot compete successfully on international markets (Seredyn, 2006). Other problems faced by beef producers are too low slaughter weight of cattle and discrepancy between feeding system and fattening ability of animals, which adversely affects carcass and meat quality (Sami et al., 2004; Basarab et al., 2007; Węglarz, 2010). In order to increase beef production and improve meat quality, $\mathrm{F}_{1}$ hybrids produced by commercial crossing could be used for fattening, and purebred beef cattle

${ }^{1}$ University of Warmia and Mazury in Olsztyn, Faculty of Animal Bioengineering, Oczapowskiego 5, 10-719 Olsztyn, Poland. *Corresponding author (zena@uwm.edu.pl).

Received: 27 August 2013.

Accepted: 17 January 2014.

doi:10.4067/S0718-58392014000100010 herds should be developed. The offspring produced by commercial crossing are characterized by higher fattening performance and higher slaughter quality (Nogalski and Kijak, 2001; Nogalski et al., 2013). The slaughter value of cattle and carcass quality are associated with participation in carcass components with higher commercial value (Śmiecińska and Wajda, 2008). Beef carcasses assigned to higher conformation classes under the EUROP scheme have higher weights of five primal cuts, and the proportions of the most valuable cuts in the carcass affect its overall quality (Choroszy et al., 2009).

Steers, compared with bulls, are characterized by a slower growth rate and lower feed efficiency, but their meat has a higher intramuscular fat content, it is lighter, tender, and has higher water-holding capacity (Purchas et al., 2002). In countries that are leaders in commercial beef production, meat from steers remains in high demand on specialty markets and it is sold to restaurants at high prices (Vieira et al., 2007). The side effects of calf castration include lower feed efficiency, lower daily gains, prolonged fattening and a high fat content of meat which is not always accepted by consumers. The benefits of castration include lowering testosterone levels, which is particularly important during the pre-slaughter period as it prevents the depletion of energy reserves required for decreasing muscle $\mathrm{pH}$ (Steen, 1995). Castration reduces 
aggressiveness (fighting between males) and prevents manifestations of sexual behavior (Price et al., 2003), thus making the animals easier and safer to handle.

Apart from genetic factors (cattle breeds used for crossing and producing hybrids), carcass quality is also determined by the animal's age and body weight (BW) at the end of fattening period. The latter factors are closely related to the feeding regime (Toro et al., 2009; Morales et al., 2012). Due to low profitability of beef production, beef cattle are usually fattened under semi-intensive conditions and are fed cheap farm-made feeds. Sharman et al. (2013) demonstrated that only feeding moderateenergy diets to steers allows producing high-quality beef with an optimal fat content. According to Lengyel et al. (2003), intramuscular fat content of beef cuts is affected by the length of fattening period and final BW of cattle. Intramuscular fat is a key driver of beef tenderness and flavor, and it is considered beneficial to consumer health. The taste and health-promoting properties of beef are determined by both the amount and quality of fat. Beef owes its specific attributes to the presence of vitamins, phospholipids, sphingomyelin, lysozyme, lactoferrin, and polyunsaturated fatty acids (PUFAs: conjugated linoleic acid [CLA], arachidonic acid [AA], docosahexaenoic acid [DHA], eicosapentaenoic acid [EPA]). The above biologically active substances are known to have antineoplastic, antioxidant, immune-boosting, and antibacterial properties. They also prevent excessive fat deposition (Harris, 2001). Conjugated linoleic acid is a potent antioxidant which prevents and inhibits cancer cell growth. A high n-6 to n-3 ratio of dietary PUFAs is considered a risk factor for some lifestyle diseases. In the modern Western diet, n-6/n-3 PUFA ratio is 10-15:1, whereas its optimal range is 2-4:1 (Breslow, 2006). A natural and cost-effective way to improve health benefits of beef could be a low-intensity feeding system based on increased roughage to concentrate ratio in the diet, aimed at reducing growth rate of finishing cattle (Rule et al., 1995). Such rations have a more desirable fatty acid profile, in comparison with diets with a high proportion of concentrates, and they positively affect fatty acid composition of animal tissue (Noci et al., 2005).

In Poland, 'Limousin' bulls are most frequently crossed with dairy cows to produce beef hybrids. The objective of this study was to determine the optimum finishing weight of young crossbred 'Polish Holstein Friesian' (PHF) $\times$ 'Limousin' (LIM) steers and bulls, fed farm-made feeds, based on their slaughter value.

\section{MATERIALS AND METHODS}

\section{Experimental material}

The experimental materials comprised 60 animals, including 30 beef bulls and 30 beef steers, produced by crossing 'Polish Holstein Friesian' (PHF) heifers and cows with 'Limousin' (LIM) bulls. Calves of known origin purchased at 2 or 3-wk of age were placed in a rearing facility at the Agricultural Experiment Station in Bałcyny. One half of calves were castrated at purchase. Bloodless castration was carried out using a rubber elastrator. Calves were fed milk replacer, hay, and concentrate, followed by haylage. Starting from 6-mo of age, steers and bulls were fattened in a semi-intensive production system. Daily gains ranged from 800 to $950 \mathrm{~g}$, and they were 50-100 $\mathrm{g}$ higher in bulls than in steers. Silage made from wilted grass (first cut), supplemented with concentrate (rapeseed meal, ground triticale, minerals) was provided ad libitum. The percentage of feedstuffs in the ration was calculated based on the energy density of diets in accordance with the Institut National de la Recherche Agronomique (INRA) feed evaluation system (INRA, 1993), using models for beef steers or commercial crosses. The average nutritional value of diets per $\mathrm{kg} \mathrm{DM}$ was $0.98 \mathrm{UFV}$ (feed unit for meat production from French unité fourragère viande) and $161 \mathrm{~g}$ total protein. Calves were fed concentrate I to $300 \mathrm{~kg} \mathrm{BW}$, followed by concentrate II (> $300 \mathrm{~kg} \mathrm{BW})$ (Table 1).

Animals were fed a total mixed ration (TMR) ad libitum, composed of grass silage and concentrate (triticale, rapeseed meal [RSM], premix) at a ratio 25:75 on a DM basis. Supplemental minerals and vitamins were provided in the form of a commercial premix for finishing cattle (Cargill Poland Ltd., Kiszkowo, code of product 7619) containing (per kg): 235 g Ca, 79 g Na, 48 g P, 28 g Mg, 500 g Fe, 2000 mg Mn, 375 mg Cu, 3750 mg Zn, $50 \mathrm{mg} \mathrm{I}, 12.5 \mathrm{mg} \mathrm{Co}, 12.50 \mathrm{mg}$ Se, $250000 \mathrm{IU}$ vitamin A, $50000 \mathrm{IU}$ vitamin $\mathrm{D}_{3}, 1000 \mathrm{mg}$ vitamin $\mathrm{E}$, and 909.10 $\mathrm{mg}$ DL alpha-tocopherol. Calves were fattened to 450 , 500,550 , or $600 \mathrm{~kg} \mathrm{BW}$, and transported over a distance of $90 \mathrm{~km}$ to the abattoir where they were kept in lairage with free access to water. After $24 \mathrm{~h}$ fasting and weighing, animals were slaughtered in accordance with industrial standards. Carcass weight was determined and carcasses were divided into half-carcasses (by cutting through the middle of vertebrae, with the tail at the right half-carcass). Half-carcasses were weighed and carcass dressing percentage (percentage ratio of carcass weight to live BW at slaughter) was calculated. Carcasses were classified into conformation classes and fat classes according to the EUROP system (Kien, 2004). Ninety-six hours post mortem, three-rib $\left(10^{\text {th }}-12^{\text {th }}\right.$ rib $)$ sections were sampled from right half-carcasses (two cuts through a half-carcass, perpendicular to the spine, between the $9^{\text {th }}$ and $10^{\text {th }}$, and the $12^{\text {th }}$ and $13^{\text {th }}$ thoracic vertebrae). Half-carcasses were divided into primal cuts in accordance with Polish Standard (Wołowina-Części zasadnicze PN-88/A-82003/ Ap1; Polski Komitet Normalizacyjny, 2004). Five most valuable cuts, i.e. shoulder, fore ribs, best ribs, loin, and round of beef were weighed and their percentage share in the right half-carcass was estimated. Three-rib cuts were dissected and percentage content of soft tissues (lean meat, fat, tendons) and bones was determined. After $96 \mathrm{~h}$ 
carcass chilling, meat samples were collected from muscle longissimus dorsi (MLD) at the level of $11^{\text {th }}-13^{\text {th }}$ thoracic vertebrae. Samples were transported under refrigerated conditions to the laboratory at the Department of Cattle Breeding and Milk Evaluation, University of Warmia and Mazury in Olsztyn, Poland.

\section{Fat extraction}

Fat was extracted from ground meat samples by the Soxhlet method using the Büchi B-811 extraction system (Büchi Labortechnik AG, Flawil, Switzerland), with hexane as solvent. Crude fat content and percentage share of fatty acids were determined based on the following standards: PN-EN ISO 5509: 2001 For animal and vegetable fats and oils, and preparation of methyl esters of fatty acids, and PN-EN ISO 5508:1996 for animal and vegetable fats and oils (Żegarska et al., 1991).

\section{Fatty acid profile}

Fatty acid methyl esters were obtained by dissolving the extracted fat in a methanol-chloroform- $\mathrm{H}_{2} \mathrm{SO}_{4}$ mixture, followed by methylation according to the modified Peisker method (Żegarska et al., 1991). The percentage share of 31 fatty acids was determined by gas chromatography, using the Varian CP 3800 system with a split/splitless injector and a flame-ionization detector (FID). Samples $(1 \mu \mathrm{L})$ of fatty acid methyl esters were placed on a CP-Sil 88 capillary column (length: $100 \mathrm{~m}$, inner diameter: $0.25 \mathrm{~mm}$ ). Data were processed using the Galaxie Chromatography Data System (Varian, Varian, Inc. Walnut Creek, California, USA). Fatty acids were identified by comparing their retention times with those of commercially available reference standards purchased from Supelco Inc. (Sigma Aldrich, St. Louis, Missouri, USA). Analyses of samples and reference standards were performed under identical conditions, i.e. carrier gashelium, injector temperature $260{ }^{\circ} \mathrm{C}$, detector temperature $260{ }^{\circ} \mathrm{C}$, initial oven temperature $110^{\circ} \mathrm{C}$ raised to $249^{\circ} \mathrm{C}$. Fatty acids were divided into the following categories: saturated fatty acids (SFAs), unsaturated fatty acids (UFAs), including monounsaturated fatty acids (MUFAs) and polyunsaturated fatty acids (PUFAs). The following ratios were calculated: UFA/SFA, PUFA/SFA, and n-6/n-3 PUFA.

\section{Statistical analysis}

Data were processed statistically using Statistica version 10.0 software (StatSoft, 2011). Within each category (bulls, steers), animals were divided into four groups based on their slaughter weight: 450, 500, 550, and 600 $\mathrm{kg}$. The effects of cattle category and slaughter weight on slaughter traits were determined by the least squares method, using the formula:

$$
\mathrm{Y}_{\mathrm{ijk}}=\mu+\mathrm{A}_{\mathrm{i}}+\mathrm{B}_{\mathrm{j}}+(\mathrm{AB})_{\mathrm{ij}}+\mathrm{e}_{\mathrm{ijk}}
$$

where $Y_{i j k}$ is value of the analyzed parameter, $\mu$ is population mean, $A_{i}$ is effect of cattle category $(1,2), B_{j}$ is effect of slaughter weight (1-4), $(A B)_{i j}$ is category $\times$ slaughter weight interaction, and $e_{i j k}$ is random error. Differences between means were estimated by Tukey's test.

\section{RESULTS AND DISCUSSION}

Bull carcasses, compared with steer carcasses, were characterized by better conformation and a higher muscle content (Table 2); significant ( $\mathrm{p} \leq 0.05$ ) differences were noted for the highest slaughter weight. In steers group, animals slaughtered at $550 \mathrm{~kg} \mathrm{BW}$ received the highest carcass conformation scores. In bulls, higher slaughter weight was associated with better carcass conformation. Increasing slaughter weight increased carcass fat content in both calf categories. Within categories, significant differences in carcass fatness were noted between the lightest and heaviest steers and bulls. Steer carcasses had a significantly higher fat content, compared with bull carcasses. A cattle category $\times$ slaughter weight interaction was noted for carcass fat content; an increase in carcass fatness with increasing slaughter weight was considerably higher in steers than in bulls. Previous studies of young

Table 1. Chemical composition and nutritional value of experimental diets (mean \pm SD).

\begin{tabular}{|c|c|c|c|c|c|}
\hline Specification & Silage & Triticale & $\begin{array}{c}\text { Rapeseed } \\
\text { meal }\end{array}$ & Concentrate I & Concentrate II \\
\hline Triticale, $\mathrm{g} \mathrm{kg}^{-1}$ & & & & 710 & 770 \\
\hline Rapeseed meal, $\mathrm{g} \mathrm{kg}^{-1}$ & & & & 250 & 190 \\
\hline $\mathrm{N}$ & 9 & 1 & 1 & 7 & 7 \\
\hline DM & $397 \pm 109.3$ & 881 & 887 & $883.9 \pm 7.1$ & $885.5 \pm 8.2$ \\
\hline \multicolumn{6}{|l|}{ On DM basis, $\mathrm{g} \mathrm{kg}^{-1}$} \\
\hline Organic matter & $920 \pm 30.6$ & 981 & 927 & $932 \pm 13.1$ & $925 \pm 18.3$ \\
\hline Crude protein & $141 \pm 11.4$ & 133 & 388 & $189 \pm 15.1$ & $163 \pm 7.1$ \\
\hline Neutral detergent fiber & $569 \pm 52.3$ & 193 & 310 & $202 \pm 11.2$ & $184 \pm 7.9$ \\
\hline Acid detergent fiber & $387 \pm 59.2$ & 44 & 228 & $72 \pm 5.8$ & $31 \pm 8.2$ \\
\hline Digestible organic matter digestibility & $741 \pm 55.9$ & $932 \pm 26.5$ & $848 \pm 4.4$ & - & - \\
\hline Meat production units (UFV) & $0.80 \pm 0.03$ & 1.21 & 1.01 & $1.18 \pm 0.03$ & $1.21 \pm 0.02$ \\
\hline PDIN $^{1}$ & $82.2 \pm 6.64$ & 89 & 259 & $122.2 \pm 2.4$ & $112.4 \pm 5.2$ \\
\hline $\mathrm{PDIE}^{2}$ & $69.5 \pm 2.28$ & 109 & 163 & $129.6 \pm 5.2$ & $121.1 \pm 4.7$ \\
\hline
\end{tabular}

${ }^{1}$ Protein digested in the small intestine depending on rumen degraded protein.

${ }^{2}$ Protein digested in the small intestine depending on rumen fermented organic matter.

Fermentation characteristics of silage: $\mathrm{pH} 4.8 \pm 0.3$, lactic acid $54 \pm 20.4 \mathrm{~g} \mathrm{~kg}^{-1} \mathrm{DM}$, volatile fatty acids $27 \pm 5.3 \mathrm{~g} \mathrm{~kg}-1 \mathrm{DM}$, water soluble carbohydrates

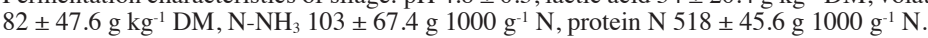


Table 2. Body weight bulls and steers at the end of fattening and results of the evaluation according to the EUROP system.

\begin{tabular}{|c|c|c|c|c|c|c|c|c|c|c|}
\hline \multirow[b]{3}{*}{ Traits } & & \multicolumn{8}{|c|}{ Body weight at the end of fattening $(\mathrm{kg})$} & \multirow[b]{3}{*}{ Interaction } \\
\hline & & \multicolumn{2}{|c|}{450} & \multicolumn{2}{|c|}{500} & \multicolumn{2}{|c|}{550} & \multicolumn{2}{|c|}{600} & \\
\hline & & $\bar{x}$ & SE & $\bar{x}$ & SE & $\bar{x}$ & $\mathrm{SE}$ & $\bar{x}$ & SE & \\
\hline \multirow[t]{2}{*}{ Number } & Steers & 7 & & 7 & & 8 & & 8 & & \\
\hline & Bulls & 7 & & 8 & & 8 & & 7 & & \\
\hline \multirow[t]{2}{*}{ Average body weight at the end of fattening, $\mathrm{kg}$} & Steers & 448.7 & 5.09 & 500.8 & 5.41 & 553.3 & 6.42 & 606.1 & 7.03 & - \\
\hline & Bulls & 461.8 & 5.38 & 497.8 & 5.55 & 548.3 & 6.03 & 608.0 & 6.02 & \\
\hline \multirow[t]{2}{*}{ Conformation score, $\mathrm{pts}^{1}$} & Steers & 9.3 & 0.64 & 8.6 & 0.68 & 8.4 & 0.50 & $8.5^{*}$ & 0.40 & - \\
\hline & Bulls & 8.6 & 0.40 & 8.1 & 0.75 & 7.8 & 0.18 & $7.7 *$ & 0.40 & \\
\hline \multirow[t]{2}{*}{ Fatness score, pts $^{2}$} & Steers & $5.0 \mathrm{~A}^{* *}$ & 0.69 & $5.2 *$ & 0.20 & $6.5 * *$ & 0.29 & $8.9 \mathrm{~B} * *$ & 0.20 & $* *$ \\
\hline & Bulls & $2.6 \mathrm{~A}^{* *}$ & 0.40 & $4.2 *$ & 0.42 & $4.4 * *$ & 0.28 & $5.0 \mathrm{~B} * *$ & 0.62 & \\
\hline \multirow[t]{2}{*}{ Dressing percentage, $\%$} & Steers & $55.93 *$ & 0.89 & 57.12 & 0.56 & 57.31 & 0.11 & 57.72 & 0.40 & - \\
\hline & Bulls & $58.53 *$ & 0.68 & 58.65 & 0.72 & 58.67 & 0.45 & 58.79 & 0.89 & \\
\hline
\end{tabular}

SE: Standard error

${ }^{1}$ EUROP conformation: 1 muscling outstanding (class E+)-15 muscling very weak (class P-).

${ }^{2}$ EUROP degree of fat cover: 1 none up to low fat cover (class 1-)-15 very high (class 5+).

Means with different letter differ within a row: A, B $(\mathrm{p} \leq 0.01)$; $\mathrm{a}, \mathrm{b}(\mathrm{p} \leq 0.05)$; within columns: $* *(\mathrm{p} \leq 0.01) ; *(\mathrm{p} \leq 0.05)$.

bulls revealed no significant effect of live BW at slaughter on carcass leanness and fatness (Keane, 2003; Albertí et al., 2005). In the present experiment, differences in fatness score of carcass were more noticeable in steers slaughtered at 550 and $600 \mathrm{~kg} \mathrm{BW}$. Carcass conformation and fat cover scores affect the market price of beef cattle (Albertí et al., 2005). Therefore, steers should not be fattened to $600 \mathrm{~kg}$ slaughter weight due to increased fat deposition in the range 550-600 $\mathrm{kg} \mathrm{BW}$. During the fattening of young cattle, fast growth of bones is followed by muscle development and fat deposition. In bulls castrated before reaching sexual maturity, androgen production is inhibited, and their carcasses contain more fat (Mach et al., 2009). In the current study, bulls had a higher carcass dressing percentage than steers, irrespective of slaughter weight. A significant difference of $2.6 \%$ was observed for the lowest slaughter weight. Dressing percentage was higher in heavier animals, which could result from higher carcass fatness, particularly in steers. In a study by Bartoň et al. (2003), crossbred beef bulls slaughtered at $550 \mathrm{~kg}$ BW had a lower carcass dressing percentage than those analyzed in our study (54.88\%), at comparable average daily gains. Litwińczuk et al. (2006) reported that carcass dressing percentage increased with increasing slaughter weights of bulls. Such a correlation was not observed in our study, most probably due to a high fat content of carcasses produced by heavier animals. Młynek et al. (2006) noted a higher muscle yield in heavier bulls.

The weights of five most valuable carcass cuts were higher in bulls; significant $(\mathrm{p} \leq 0.05)$ differences were observed for the highest slaughter weight (Table 3). The percentage content of five primal cuts, determined for different slaughter weights, varied between calf categories . In bulls, their percentage share of the half-carcass tended to increase with increasing slaughter weight, whereas in steers the lowest percentage content of five primal cuts was noted in the heaviest animals. A significant difference of $4.96 \%$ in mean values was observed between the heaviest bulls and steers. Muscle longissimus dorsi is a high-value section of the beef carcass, associated with lean meat content (Nogalski et al., 2013). Bulls had heavier MLD than steers, and significant differences were found for the lowest and highest slaughter weights. The percentage share of MLD in the half-carcass was higher in bulls, and significant differences were noted for slaughter weight $450 \mathrm{~kg}$. There was a significant ( $\mathrm{p}$ $\leq 0.05$ ) interaction between live $\mathrm{BW}$ at slaughter and cattle category for the percentage content of MLD in halfcarcass. The cross-sectional area of MLD increased with increasing slaughter weight, and higher values of this trait

Table 3. Selected carcass quality parameters.

\begin{tabular}{|c|c|c|c|c|c|c|c|c|c|c|}
\hline \multirow[b]{3}{*}{ Traits } & & \multicolumn{8}{|c|}{ Body weight at the end of fattening $(\mathrm{kg})$} & \multirow[b]{3}{*}{ Interaction } \\
\hline & & \multicolumn{2}{|c|}{450} & \multicolumn{2}{|c|}{500} & \multicolumn{2}{|c|}{550} & \multicolumn{2}{|l|}{600} & \\
\hline & & $\bar{x}$ & SE & $\bar{x}$ & SE & $\bar{x}$ & SE & $\bar{x}$ & $\mathrm{SE}$ & \\
\hline Weight of five primal cuts, $\mathrm{kg}$ & $\begin{array}{l}\text { Steers } \\
\text { Bulls }\end{array}$ & $\begin{array}{l}69.3 \\
70.5\end{array}$ & $\begin{array}{l}3.72 \\
2.63\end{array}$ & $\begin{array}{l}74.6 \\
77.2\end{array}$ & $\begin{array}{l}1.67 \\
3.36\end{array}$ & $\begin{array}{l}84.7 \\
88.2\end{array}$ & $\begin{array}{l}1.36 \\
2.10\end{array}$ & $\begin{array}{l}87.3 \\
96.5\end{array}$ & $\begin{array}{l}2.31 \\
2.05\end{array}$ & - \\
\hline $\begin{array}{l}\text { Share of five primal cuts in the right half- } \\
\text { carcass, \% }\end{array}$ & $\begin{array}{l}\text { Steers } \\
\text { Bulls }\end{array}$ & $\begin{array}{l}57.56 \mathrm{~A} \\
57.05\end{array}$ & $\begin{array}{l}0.36 \\
0.59\end{array}$ & $\begin{array}{l}55.96 \\
58.47\end{array}$ & $\begin{array}{l}0.24 \\
0.89\end{array}$ & $\begin{array}{l}57.52 \\
58.67\end{array}$ & $\begin{array}{l}0.53 \\
0.98\end{array}$ & $\begin{array}{l}53.45 \mathrm{~B} * * \\
58.41 * *\end{array}$ & $\begin{array}{l}0.35 \\
0.62\end{array}$ & - \\
\hline Weight of m. Longissimus dorsi, $\mathrm{kg}$ & $\begin{array}{l}\text { Steers } \\
\text { Bulls }\end{array}$ & $\begin{array}{r}8.8 \\
11.6\end{array}$ & $\begin{array}{l}0.93 \\
0.81\end{array}$ & $\begin{array}{l}10.2 \\
10.4 \mathrm{a}\end{array}$ & $\begin{array}{l}0.78 \\
0.68\end{array}$ & $\begin{array}{l}10.2 \\
12.1\end{array}$ & $\begin{array}{l}0.78 \\
0.82\end{array}$ & $\begin{array}{l}11.4 \\
14.7 \mathrm{~b}\end{array}$ & $\begin{array}{l}0.35 \\
0.70\end{array}$ & - \\
\hline $\begin{array}{l}\text { Share of } m \text {. Longissimus dorsi in the right half- } \\
\text { carcass, } \%\end{array}$ & $\begin{array}{l}\text { Steers } \\
\text { Bulls }\end{array}$ & $\begin{array}{l}7.56 \\
9.34\end{array}$ & $\begin{array}{l}0.75 \\
0.59\end{array}$ & $\begin{array}{l}7.83 \\
7.54\end{array}$ & $\begin{array}{l}0.53 \\
0.89\end{array}$ & $\begin{array}{l}6.88 \\
7.99\end{array}$ & $\begin{array}{l}0.55 \\
0.50\end{array}$ & $\begin{array}{l}7.08 \\
8.82\end{array}$ & $\begin{array}{l}0.19 \\
0.35\end{array}$ & $*$ \\
\hline Muscle Longissimus dorsi area, $\mathrm{cm}^{2}$ & $\begin{array}{l}\text { Steers } \\
\text { Bulls }\end{array}$ & $\begin{array}{l}79.8 \\
83.1 \mathrm{a}\end{array}$ & $\begin{array}{l}5.35 \\
3.26\end{array}$ & $\begin{array}{l}91.3 \\
86.3 \mathrm{a}\end{array}$ & $\begin{array}{l}3.72 \\
5.12\end{array}$ & $\begin{array}{l}95.1 \\
97.8\end{array}$ & $\begin{array}{l}2.50 \\
4.21\end{array}$ & $\begin{array}{c}91.5 \\
102.7 \mathrm{~b}\end{array}$ & $\begin{array}{l}2.38 \\
2.80\end{array}$ & - \\
\hline $\begin{array}{l}\text { Content of intramuscular fat in muscle } \\
\text { Longissimus dorsi, } \%\end{array}$ & $\begin{array}{l}\text { Steers } \\
\text { Bulls }\end{array}$ & $\begin{array}{l}1.42 \mathrm{~A} \\
1.01\end{array}$ & $\begin{array}{l}0.33 \\
0.09\end{array}$ & $\begin{array}{l}1.99 \mathrm{a} \\
1.18\end{array}$ & $\begin{array}{l}0.46 \\
0.15\end{array}$ & $\begin{array}{l}2.26 \\
1.32\end{array}$ & $\begin{array}{l}0.37 \\
0.34\end{array}$ & $\begin{array}{l}3.27 \mathrm{Bb} * * \\
1.52 * *\end{array}$ & $\begin{array}{l}0.48 \\
0.40\end{array}$ & - \\
\hline
\end{tabular}

Means with different letter differ within a row: A, B ( $\mathrm{p} \leq 0.01)$; a, b $(\mathrm{p} \leq 0.05)$; within columns: ** $(\mathrm{p} \leq 0.01) ; *(\mathrm{p} \leq 0.05)$. 
were noted in bulls. In beef cattle, an increase in BW is usually accompanied by an increase in the cross-sectional area of MLD (Keane, 2003; Opatpatanakit et al., 2004; 2007). In the present study, a significant effect of live BW at slaughter on the cross-sectional area of MLD was observed only in bulls, which points to a longer period of muscle tissue growth in bulls compared with steers. The cross-sectional area of MLD was smaller in steers slaughtered at $600 \mathrm{~kg} \mathrm{BW}$ than in those slaughtered at 550 $\mathrm{kg} \mathrm{BW}$.An increase in slaughter weight from 500 to $600 \mathrm{~kg}$ contributes to a higher proportion of high-value cuts in the carcass, in particular the rump (Sethakul et al., 2007). In our study, the proportion of five most valuable cuts in the half-carcass tended to increase with increasing slaughter weight in bulls. In steers, due to increased fat deposition, the percentage share of high-value cuts decreased in the heaviest animals, in comparison with those slaughtered at lower BW.

Intramuscular fat content increased with increasing slaughter weight, regardless of cattle category. In steers with the highest slaughter weight, the intramuscular content of MLD reached $3.27 \%$, and the noted value was significantly higher than those determined for steers slaughtered at 450 and $500 \mathrm{~kg}$ BW. Lengyel et al. (2003) demonstrated that in HF steers, the intramuscular content of MLD increased considerably with age at slaughter. Fattening to higher weights significantly improves intramuscular fat content (Bruns et al., 2004). In the current study, intramuscular fat content was nearly twofold higher $(\mathrm{p} \leq 0.01)$ in the heaviest steers, compared with bulls. Sharman et al. (2013) infer from the research that intramuscular fat tends to develop in a linear relationship with carcass weight, and that only a moderate level of energy intake is required for lipid filling of intramuscular adipocytes.

The tissue composition of three-rib cuts varied significantly between bulls and steers (Table 4). In steers, lean meat content decreased and fat content increased with increasing slaughter weight. In bulls, live BW at slaughter had no significant effect on the lean meat and fat content of the three-rib cut. Cuts from bull carcasses had a higher lean meat content than cuts from steer carcasses, with average differences ranging from $2 \%$ to $11.29 \%$. Bulls and steers differed also considerably with respect to fat content. Bone content was higher in bulls than in steers. An interaction between live BW at slaughter and cattle category, noted for the proportions of lean meat, fat and bones in the three-rib cut, resulted from a high fat content of carcasses produced by the heaviest steers. A study conducted in Ireland revealed that fattening crossbred $(\mathrm{HF} \times$ Italian beef cattle breeds) steers to 600 $\mathrm{kg}$ had no significant effect on carcass fatness measured as the fat content of the hind quarter (Keane and Allen, 2002). Stehen and Kilpatrick (1995) demonstrated that in 'Limousin' $\times$ 'Friesian' bulls, steers, and heifers, increasing slaughter age and weight contributed to a higher carcass fat content estimated from the dissection of fore-rib joints, particularly in heifers and steers, and to a lesser extent in bulls. In the present study, fat content increased substantially and lean meat content decreased in the three-rib cut of steers already at $550 \mathrm{~kg} \mathrm{BW}$. In view of carcass tissue composition, the optimal slaughter weight of the analyzed crossbred steers is $500 \mathrm{~kg}$.

Cattle category and slaughter weight had no effect on the share of UFAs in the total fatty acid pool in intramuscular fat (Table 5). Intramuscular fat extracted from bull carcasses contained significantly $(\mathrm{p} \leq 0.05)$ higher PUFA concentrations, compared with steer carcasses. A highly

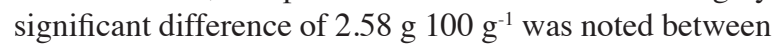
the heaviest bulls and steers. The concentrations of n-6 PUFAs were also significantly higher in the intramuscular fat of bulls. The lightest steers were characterized by a significantly lower n-6/n-3 PUFA ratio. One of the major risk factors for cardiovascular diseases in humans is too high dietary intake of n-6 PUFAs and too low intake of n-3 PUFAs, resulting in a high n-6/n-3 PUFA ratio (Breslow, 2006). In our experiment, the slaughter weights of bulls and steers had no effect on the n-6/n-3 PUFA ratio in intramuscular fat. The optimal n-6/n-3 dietary ratio of 5:1 was not exceeded, and in the group of the lightest animals it was more desirable in steers than in bulls. Bilik et al. (2009) demonstrated that the fatty acid composition of meat from bulls was more favorable when the animals were fattened semi-intensively with a higher proportion of bulky feeds in the diet, compared with intensive fattening. The above findings were confirmed by Morales et al. (2012), who noted the lowest n-6/n-3 PUFA ratio in the intramuscular fat of MLD in grazed steers. De Smet

Table 4. Tissue composition of three-rib cuts $(\%)$.

\begin{tabular}{|c|c|c|c|c|c|c|c|c|c|c|}
\hline & & \multicolumn{8}{|c|}{ Body weight at the end of fattening $(\mathrm{kg})$} & \multirow[b]{3}{*}{ Interaction } \\
\hline & & 4 & & 50 & & 5 & & 60 & & \\
\hline \multicolumn{2}{|c|}{ Share in three-rib cuts } & $\bar{x}$ & $\mathrm{SE}$ & $\bar{x}$ & SE & $\bar{x}$ & SE & $\bar{x}$ & SE & \\
\hline \multirow[t]{2}{*}{ Lean meat } & Steers & $52.74 \mathrm{a} * *$ & 1.53 & $55.86 \mathrm{~A}$ & 2.50 & $49.18 \mathrm{~B} * *$ & 0.85 & $47.78 \mathrm{Bb} * *$ & 1.45 & * \\
\hline & Bulls & $59.19 * *$ & 1.83 & 57.86 & 1.13 & $60.47 * *$ & 1.02 & $58.06^{* *}$ & 1.61 & \\
\hline \multirow[t]{2}{*}{ Fat } & Steers & $21.25 \mathrm{~A}^{* *}$ & 1.46 & $23.18 \mathrm{~A}^{* *}$ & 1.84 & $29.23 \mathrm{~B} * *$ & 0.82 & $31.68 \mathrm{~B} * *$ & 2.09 & $*$ \\
\hline & Bulls & $13.33 * *$ & 1.08 & $17.15^{* *}$ & 0.86 & $13.84 * *$ & 0.97 & $16.68 * *$ & 1.34 & \\
\hline \multirow[t]{2}{*}{ Bones } & Steers & $21.72 \mathrm{~A}$ & 0.91 & $17.29 \mathrm{~B}^{*}$ & 1.28 & $17.07 \mathrm{~B} * *$ & 0.82 & $15.29 \mathrm{~B} * *$ & 0.31 & $*$ \\
\hline & Bulls & $23.08 \mathrm{a}$ & 0.95 & $20.24 b *$ & 0.62 & $21.81^{* *}$ & 0.53 & $21.51 * *$ & 1.09 & \\
\hline \multirow[t]{2}{*}{ Tendons } & Steers & 4.28 & 0.47 & 3.66 & 0.24 & 4.51 & 0.62 & 5.24 & 0.66 & - \\
\hline & Bulls & 4.39 & 0.54 & 4.73 & 0.67 & 3.87 & 0.43 & 3.74 & 0.49 & \\
\hline
\end{tabular}

Means with different letter differ within a row: A, B ( $\leq \leq 0.01)$; a, b ( $\leq 0.05)$; within columns: ** $(\mathrm{p} \leq 0.01) ; *(\mathrm{p} \leq 0.05)$. 
Table 5. Effect of sex and body weight at the end of fattening on fatty acid groups and ratios in intramuscular fat.

\begin{tabular}{|c|c|c|c|c|c|c|c|c|c|c|}
\hline \multirow{3}{*}{\multicolumn{2}{|c|}{$\begin{array}{l}\text { Fatty acid, g } 100 \mathrm{~g}^{-1} \\
\text { total fatty } \\
\text { acids }\end{array}$}} & \multicolumn{8}{|c|}{ Body weight at the end of fattening $(\mathrm{kg})$} & \multirow[b]{3}{*}{ Interaction } \\
\hline & & \multicolumn{2}{|c|}{450} & \multicolumn{2}{|c|}{500} & \multicolumn{2}{|c|}{550} & \multicolumn{2}{|c|}{600} & \\
\hline & & $\bar{x}$ & SE & $\bar{x}$ & SE & $\bar{x}$ & SE & $\bar{x}$ & SE & \\
\hline \multirow[t]{2}{*}{ SFA } & Steers & 49.89 & 0.962 & 50.80 & 1.164 & 49.54 & 1.876 & 49.15 & 0.614 & \multirow[t]{2}{*}{ - } \\
\hline & Bulls & 50.87 & 0.592 & 51.32 & 1.417 & 50.30 & 0.702 & 49.33 & 1.334 & \\
\hline \multirow[t]{2}{*}{ UFA } & Steers & 50.10 & 0.954 & 49.30 & 1.105 & 50.46 & 1.874 & 50.85 & 0.613 & \multirow[t]{2}{*}{ - } \\
\hline & Bulls & 49.13 & 0.592 & 48.66 & 1.414 & 49.71 & 0.701 & 50.82 & 1.342 & \\
\hline \multirow[t]{2}{*}{ MUFA } & Steers & $45.83^{*}$ & 1.212 & 45.84 & 1.024 & 46.48 & 1.743 & 47.22 & 0.687 & \multirow[t]{2}{*}{ - } \\
\hline & Bulls & $42.43^{*}$ & 0.955 & 43.13 & 1.429 & 43.44 & 1.199 & 44.61 & 0.989 & \\
\hline \multirow[t]{2}{*}{ PUFA } & Steers & $4.26^{*}$ & 0.570 & $3.46^{*}$ & 0.243 & $3.97 *$ & 0.251 & $3.63 * *$ & 0.380 & \multirow[t]{2}{*}{ - } \\
\hline & Bulls & $6.69 *$ & 0.648 & $5.52 *$ & 0.258 & $6.27 *$ & 0.806 & $6.21 * *$ & 0.913 & \\
\hline \multirow[t]{2}{*}{ PUFA/SFA } & Steers & 0.085 & 0.011 & 0.069 & 0.005 & 0.081 & 0.007 & 0.074 & 0.008 & \multirow[t]{2}{*}{ - } \\
\hline & Bulls & 0.131 & 0.012 & 0.108 & 0.006 & 0.124 & 0.016 & 0.128 & 0.021 & \\
\hline \multirow[t]{2}{*}{$n-3$} & Steers & 1.27 & 0.228 & 0.88 & 0.091 & $1.02 *$ & 0.077 & 0.88 & 0.123 & \multirow[t]{2}{*}{ - } \\
\hline & Bulls & 1.59 & 0.134 & 1.41 & 0.164 & $1.58 *$ & 0.172 & 1.40 & 0.153 & \\
\hline \multirow[t]{2}{*}{$n-6$} & Steers & $2.59 * *$ & 0.318 & $2.21 *$ & 0.193 & $2.54^{*}$ & 0.186 & $2.23 *$ & 0.250 & \multirow[t]{2}{*}{ - } \\
\hline & Bulls & $4.64 * *$ & 0.513 & $3.49 *$ & 0.148 & $4.11^{*}$ & 0.585 & $3.90 *$ & 0.657 & \\
\hline \multirow[t]{2}{*}{$n-6 / n-3$} & Steers & $2.20 *$ & 0.178 & 2.64 & 0.284 & 2.52 & 0.223 & 2.62 & 0.085 & \multirow[t]{2}{*}{ - } \\
\hline & Bulls & $2.93 *$ & 0.258 & 2.56 & 0.200 & 2.51 & 0.130 & 2.70 & 0.182 & \\
\hline
\end{tabular}

SFA: saturated fatty acids; UFA: unsaturated fatty acids; MUFA: monounsaturated fatty acids; PUFA: polyunsaturated fatty acids

Means with different letter differ within a row: A, B ( $\mathrm{p} \leq 0.01)$; $\mathrm{a}, \mathrm{b}(\mathrm{p} \leq 0.05)$; within columns: ** $(\mathrm{p} \leq 0.01)$; * $(\mathrm{p} \leq 0.05)$.

et al. (2000) demonstrated that an increased fat content of bovine meat was paralleled by increased proportions of SFAs and MUFAs and a decreased proportion of PUFAs. In the current study, a higher intramuscular fat content of meat was accompanied by a considerable increase in MUFA concentrations and a decrease in PUFA levels with no increase in the share of SFAs, which could result from feeding grass silage ad libitum.

The proportion of selected essential fatty acids in the total fatty acid pool in intramuscular fat was affected by cattle category (Table 6). The intramuscular fat of bulls contained significantly larger amounts of linoleic and linolenic acids, and higher concentrations of EPA, DPA, and DHA, compared with the intramuscular fat of steers. Irrespective of the cattle category, the share of oleic acid in the total fatty acid pool increased with increasing slaughter weight. Concentrations of linoleic acid $(\mathrm{C} 18: 3)$ were significantly $(\mathrm{P} \leq 0.05)$ higher in fat samples collected from bull carcasses than in those taken from steer carcasses. The share of CLA in the total fatty acid pool was significantly higher in bulls, and it reached the highest level in the heaviest animals (Figure 1). Conjugated linoleic acid (CLA) is formed by a precursor, the 18:1 t-11 fatty acid (trans-vaccenic acid), which is an intermediate fatty acid in the biohydrogenation process of the 18:2 n-6 fatty acid in the rumen, and this fatty acid can be transformed into CLA $(18: 2 c-9, t-11)$ by the delta-9desaturase enzyme in the tissue of ruminants after being absorbed (Griinari et al., 2000). The PUFA/SFA ratio is meat from ruminants is undesirably low, mostly due to hydrogenation of dietary UFAs by the rumen microflora (Choi et al., 2000). The recommended values of the PUFA/ SFA ratio are higher than 0.45 (Department of Health and Social Security, 1984). In the present study, the PUFA/ SFA ratio in intramuscular fat ranged from 0.069 to 0.085 g $100 \mathrm{~g}^{-1}$ in steers, and it was significantly higher in bulls at $0.108-0.131 \mathrm{~g} 100 \mathrm{~g}^{-1}$. Ruiz et al. (2005) observed a higher PUFA/SFA ratio in the muscles of bulls $(0.25)$ than

Table 6. Effect of sex and body weight at the end of fattening on functional fatty acid content in intramuscular fat.

\begin{tabular}{|c|c|c|c|c|c|c|c|c|c|c|}
\hline \multirow{3}{*}{$\begin{array}{l}\text { Fatty acid, g } 100 \mathrm{~g}^{-1} \\
\text { of total fatty } \\
\text { acids }\end{array}$} & & \multicolumn{8}{|c|}{ Body weight at the end of fattening $(\mathrm{kg})$} & \multirow[b]{3}{*}{ Interaction } \\
\hline & & \multicolumn{2}{|c|}{450} & \multicolumn{2}{|c|}{500} & \multicolumn{2}{|c|}{550} & \multicolumn{2}{|c|}{600} & \\
\hline & & $\bar{x}$ & $\overline{\mathrm{SE}}$ & $\bar{x}$ & $\overline{\mathrm{SE}}$ & $\bar{x}$ & $\overline{\mathrm{SE}}$ & $\bar{x}$ & $\overline{\mathrm{SE}}$ & \\
\hline \multirow[t]{2}{*}{ C 18:1 trans 11 (TVA) } & Steers & 1.372 & 0.072 & 1.212 & 0.055 & 1.243 & 0.075 & 1.348 & 0.081 & - \\
\hline & Bulls & 1.291 & 0.058 & 1.341 & 0.090 & 1.364 & 0.049 & 1.437 & 0.069 & \\
\hline \multirow[t]{2}{*}{ C $18: 1$ cis (OA) } & Steers & 36.93 & 0.831 & 37.68 & 0.747 & $38.75^{*}$ & 1.758 & 39.35 & 0.710 & - \\
\hline & Bulls & 34.63 & 0.925 & 34.92 & 1.281 & $35.27^{*}$ & 1.311 & 36.27 & 1.003 & \\
\hline \multirow[t]{2}{*}{ C $18: 2(\mathrm{LA})$} & Steers & $2.141 * *$ & 0.207 & $1.910 *$ & 0.140 & $2.137 *$ & 0.111 & $1.947 *$ & 0.237 & - \\
\hline & Bulls & $3.848 * *$ & 0.330 & $3.026^{*}$ & 0.161 & $3.372 *$ & 0.456 & $3.229 *$ & 0.548 & \\
\hline \multirow[t]{2}{*}{ C $18: 3$ (LNA) } & Steers & $0.594 *$ & 0.068 & 0.513 & 0.042 & $0.560 *$ & 0.030 & $0.535^{*}$ & 0.059 & - \\
\hline & Bulls & $0.956^{*}$ & 0.052 & 0.785 & 0.069 & $0.888 *$ & 0.112 & $0.859^{*}$ & 0.126 & \\
\hline \multirow{2}{*}{ C 20:4 (AA) } & Steers & 0.456 & 0.119 & 0.305 & 0.072 & 0.405 & 0.088 & $0.284 *$ & 0.024 & - \\
\hline & Bulls & 0.800 & 0.202 & 0.469 & 0.055 & 0.747 & 0.138 & $0.673^{*}$ & 0.120 & \\
\hline \multirow[t]{2}{*}{ C 20:5 (EPA) } & Steers & 0.098 & 0.040 & 0.079 & 0.027 & $0.056 *$ & 0.028 & 0.081 & 0.035 & - \\
\hline & Bulls & 0.122 & 0.027 & 0.119 & 0.017 & $0.162 *$ & 0.010 & 0.129 & 0.020 & \\
\hline \multirow[t]{2}{*}{ C $22: 5$ (DPA) } & Steers & 0.292 & 0.038 & 0.180 & 0.046 & 0.225 & 0.029 & 0.223 & 0.043 & - \\
\hline & Bulls & 0.343 & 0.066 & 0.252 & 0.021 & 0.380 & 0.054 & 0.310 & 0.039 & \\
\hline \multirow{2}{*}{ C 22:6 (DHA) } & Steers & 0.119 & 0.094 & 0.018 & 0.004 & 0.079 & 0.048 & 0.012 & 0.002 & - \\
\hline & Bulls & 0.029 & 0.005 & 0.082 & 0.041 & 0.079 & 0.024 & 0.070 & 0.025 & \\
\hline
\end{tabular}

TVA: trans-vaccenic acid; OA: oleic acid; LA: linoleic acid; LNA: linolenic acid; AA: arachidonic acid; EPA: eicosapentaenoic acid; DPA: docosapentaenoic acid; DHA: docosahexaenoic acid.

Means with different letter differ within a row: A, B $(\mathrm{p} \leq 0.01)$; $\mathrm{a}, \mathrm{b}(\mathrm{p} \leq 0.05)$; within columns: ** $(\mathrm{p} \leq 0.01)$; $(\mathrm{p} \leq 0.05)$. 


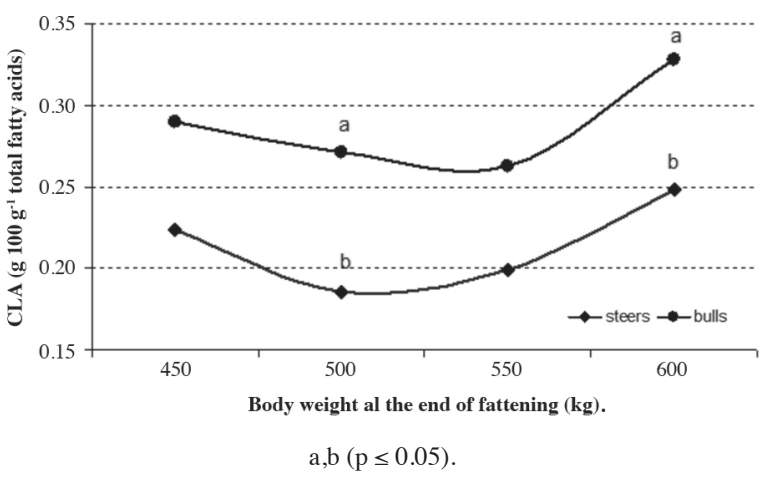

Figure 1. Effect of sex and body weight at the end of fattening on the conjugated linoleic acid (CLA) content in intramuscular fat.

of steers (0.16); both values were higher than those noted in our study.

\section{CONCLUSIONS}

Bulls, compared with steers, were characterized by a higher slaughter value. In steers, an increase in live body weight was accompanied by a considerable increase in fat content (higher than in bulls). The intramuscular fat of bulls was characterized by higher concentrations of fatty acids delivering health benefits, and a more desirable PUFA/SFA ratio. Semi-intensive fattening of 'Polish Holstein Friesian' $x$ 'Limousin' bulls to slaughter weight of $600 \mathrm{~kg}$ is recommended due to an increase in carcass value. Steers should be fattened to slaughter weight of $500-550 \mathrm{~kg}$ to prevent excessive fat deposition.

\section{ACKNOWLEDGEMENTS}

Research was realized within the project "Optimising of beef production in Poland according 217 to fork-to farm strategy" nr PO IG 01.03.01-00-204 co-financed by the European Union from 218 the European Regional Development Fund within the Innovative Economy Operational 219 Program 2007-2013.

\section{LITERATURE CITED}

Albertí, P., G. Ripoll, F. Goyache, F. Lahoz, J.L. Olleta, and B. Panea. 2005. Carcass characterization of seven Spanish beef breeds slaughtered at two commercial weights. Meat Science 71:514-521.

Bartoň, L., V. Teslík, R. Zahrádková, and D. Bureš. 2003. Growth, feed efficiency and carcass characteristics of Czech Pied and Holstein bulls. Czech Journal of Animal Science 48:459-465.

Basarab, J.A., J.L. Aalhus, M.A. Shah, P.S. Mir, V.S. Baron, M. Dugan, et al. 2007. Effect of feeding sunflower seeds on the performance, carcass characteristics, meat quality, retail stability and sensory characteristics of pasture-fed and feedlot finished beef. Canadian Journal of Animal Science 87:15-27.

Bilik, K., K. Węglarzy, and Z. Choroszy. 2009. Effect of feeding intensity of Limousin bulls on production parameters and dietetic properties of meat (in Polish). Roczniki Naukowe Zootechniki 36:63-73.
Breslow, J.L. 2006. n-3 Fatty acids and cardiovascular disease. American Journal of Clinical Nutrition 83:1477-1482.

Bruns, K.W., R.H. Pritchard, and D.L. Boggs. 2004. The relationship among body weight, body composition, and intramuscular fat content in steers. Journal of Animal Science 82:1315-1322.

Choi, N.J., M. Enser, J.D. Wood, and N.D. Scollan. 2000. Effect of breed on the deposition in beef muscle and adipose tissue of dietary n-3 polyunsaturated fatty acids. Animal Science 71:509-519.

Choroszy, B., Z. Choroszy, and P. Topolski. 2009. Analysis of the tissue composition of Simmental bull carcasses according to EUROP muscling grade (In Polish). Roczniki Naukowe Zootechniki 36:17-23.

Department of Health and Social Security. 1984. Department of Health and Social Security. Report on Health and Social Subjects No. 28. Diet and Cardiovascular Disease HMSO, London, UK.

De Smet, S., E.C. Webb, E. Claeys, L. Uytterhaegen, and D.I. Demeyer. 2000. Effect of dietary energy and protein levels on fatty acid composition of intramuscular fat in double-muscled Belgian Blue bulls. Meat Science 56:73-79.

Griinari, J.M., S.H. Corl, P.Y. Lacy, K.V.V. Chouinard, and D.E. Bauman. 2000. Conjugated linoleic acid is synthesized endogenously in lactating dairy cows by delta- 9 . The Journal of Nutrition 130:2285-2291.

Harris, W.S. 2001. Omega 3 fatty acids and human chylomicron metabolism. World Review of Nutrition and Dietetics 88:163-167.

INRA. 1993. Nutrition standards for cattle, sheep and goats - the nutritional value of feed for ruminants (in Polish). Instytut Zootechniki Kraków. Opracowane według. Institut National de la Recherche Agronomique (INRA), Paris, France.

Keane, M.G. 2003. Beef production from Holstein-Friesian bulls and steers of New Zealand and European-American descent and Belgian Blue Holstein-Friesians slaughtered at two weights. Livestock Production Science 84:207-218.

Keane, M.G., and P. Allen. 2002. A comparison of Friesian-Holstein, Piemontese-Friesian-Holstein and Romagnola-Friesian-Holstein steers for beef production and carcass traits. Livestock Production Science 78:143-158.

Kien, S. 2004. The classification of carcases of adult bovine animals in the EUROP. Meat and Fat Research Institute, Warsaw, Division in Poznań, Poland.

Lengyel, Z., F. Husveth, P. Polgar, F. Szabo, and L. Magyar. 2003. Fatty acid composition of intramuscular lipids in various muscles of Holstein-Friesian bulls slaughtered at different ages. Meat Science 65:593-598.

Litwińczuk, Z., J. Barłowska, M. Florek, and K. Tabała. 2006. Slaughter value of heifers, cows and young bulls from commercial beef production in the central-eastern region of Poland. Animal Science Papers and Reports 24:187-194.

Mach, N., A. Bach, C.E. Realini, M. Furnols, A. Velarde, and M. Devant. 2009. Burdizzo pre-pubertal castration effects on performance, behaviour carcass characteristics, and meat quality of Holstein bulls fed high-concentrate diets. Meat Science 81:329334.

Młynek, K., G. Elminowska-Wenda, and P. Guliński. 2006. The relationship between microstructure of Longissimus lumborum muscle and carcass quality of bulls slaughtered at three ages. Animal Science Papers and Reports 24:57-63.

Morales, M., C. Folch, S. Iraira, N. Teuber, and C.E. Realini. 2012. Nutritional quality of beef produced in Chile from different production systems. Chilean Journal of Agricultural Research 72:80-86.

Noci, F., F.J. Monahan, P. French, and A.P. Maloney. 2005. The fatty acid composition of muscle fat and subcutaneous adipose tissue of pasture-fed beef heifers: Influence of the duration of grazing. Journal of Animal Science 83:1167-1178.

Nogalski, Z., and Z. Kijak. 2001. Fattening performance and slaughter value of the offspring of Black and White cows and Welsh Black bulls. Czech Journal of Animal Science 46:68-73. 
Nogalski, Z., M. Wroński, Z. Wielgosz-Groth, P. Purwin, M Sobczuk-Szul, M. Mochol, et al. 2013. The effect of carcass conformation class (EUROP system) on the slaughter quality of young crossbred beef bulls and Holstein-Friesians. Annals of Animal Science 13:23-28.

Opatpatanakit, Y., J. Sethakul, K. Tunvisoottikul, and M. Chongcharoen. 2004. Return of high quality meat production from crossbred Charolais. p. 307-314. Proceeding of the $42^{\text {nd }}$ Kasetsart University Annual Conference, Bangkok. 3-6 February. Kasetsart University, Bangkok, Thailand.

Opatpatanakit, Y., J. Sethakul, K. Tunvisoottikul, and W. Promin. 2007. Factors affecting on carcass quality of feedlot steers under production system of Kamphaengsaen beef cooperative. Beef production. p. 171-178. In Proceeding of the $45^{\text {th }}$ Kasetsart University Annual Conference, Bangkok. 30 January-2 February. Kasetsart University, Bangkok, Thailand.

Price, E.O., T.E. Adams, C.C. Huxsoll, and R.E. Borgwardt. 2003. Aggressive behavior is reduced in bulls actively immunized against gonadotropin-releasing hormone. Journal of Animal Science 81:411-415.

Purchas, R.W., D.L. Burnham, and S.T. Morris. 2002. Effects of growth potential and growth path on tenderness of beef longissimus muscle from bulls and steers. Journal of Animal Science 80:3211-3221.

Ruiz, M.R., M. Matsushita, J.V. Visentainer, J.A. Hernandez, and E.L.A. Ribeiro. 2005. Proximate chemical composition and fatty acid profiles of Longissimus thoracis from pasture-fed LHRH immunocastrated and intact Bos indicus bulls. Journal of Animal Science 83:13-18.

Rule, D.C., S.B. Smith, and J.R. Romans. 1995. Fatty acid composition of muscle and adipose tissue of meat animals. $p$. 144-165. In Smith, S.B., and D.R. Smith (eds.) The biology of fat in meat animals. American Society of Animal Science (ASAS), Champaign, Illinois, USA.

Sami, A.S., C. Augustini, and F.J. Schwarz. 2004. Effects of feeding intensity and time on feed on performance, carcass characteristics and meat quality of Simmental bulls. Meat Science 67:195-201.

Seredyn, K. 2006. Slaughter value of beef carcasses in Poland and their position on the Community market (in Polish). Mięso i Wędliny 8:10-12.
Sethakul, J., Y. Opatpatanakit, K. Tunvisoottikul, and W. Promin. 2007. Retail cuts percentage and meat quality of feedlot steers under production system of Kamphaengsaen beef cooperative. Beef production. p. 179-186. In Proceeding of the $45^{\text {th }}$ Kasetsart University Annual Conference, Bangkok. 30 January-2 February. Kasetsart University, Bangkok, Thailand.

Sharman, E.D., P.A. Lancaster, C.P. McMurphy, A.J. Garmyn, B.J Pye, G.G. Hilton, et al. 2013. Effect of rate of gain of steers during the stocker phase. I. Partitioning of fat among depots and carcass characteristics. Journal of Animal Science 91:2264-2277.

Śmiecińska, K., and S. Wajda. 2008. Meet quality of cows rated among different grades under the post slaughter EUROP Classification System (in Polish). Żywność. Nauka. Technologia. Jakość 3(58):57-66.

StatSoft. 2011. Statistica (data analysis software system), Version 10.0. StatSoft, Tulsa, Oklahoma, USA.

Steen, R.W.J. 1995. The effect of plane of nutrition and slaughter weight on growth and food efficiency in bulls, steers and heifers of three breed crosses. Livestock Production Science 42:1-11.

Stehen, R.W.J., and D.J. Kilpatrick. 1995. Effects of plane nutrition and slaughter weight on the carcass composition of serially slaughtered bulls, steers and heifers of three breed crosses. Livestock Production Science 43:205-213.

Toro, P., A. Catrileo, C. Aguilar, and R. Vera. 2009. Modeling supplementation strategies for beef steer rearing and fattening system in Southern Chile. Chilean Journal of Agricultural Research 69:207-213.

Vieira, C., A. Cerdeño, E. Serrano, P. Lavín, and A.R. Mantecón. 2007. Breed and ageing extent on carcass and meat quality of beef from adult steers (oxen). Livestock Science 107:62-69.

Weglarz, A. 2010. Beef quality as related to slaughter weight of bulls as related to weight at slaughter. Annals of Animal Science 10:467-476.

Polski Komitet Normalizacyjny. 2004. Wołowina - Części zasadnicze PN-88/A-82003/Ap1. Polski Komitet Normalizacyjny, Warsaw, Poland.

Żegarska, Z., J. Jaworski, and Z. Borejszo. 1991. Ocena zmodyfikowanej metody Peiskera otrzymywania estrów metylowych kwasów tłuszczowych. Acta Academiae Agriculturae AC Technicae Olstenensis 24:25-33 (in Polish). 